Ivan Nikolić

Zoran Dimić

Univerzitet u Nišu, Filozofski fakultet
УДК 378.147:1]:316.64-057.875

Оригинални научни рад

Примљено: 24. 08. 2020.

https://doi.org/10.46630/gflz.3.2021.03

\title{
UTICAJ KURSEVA FILOZOFIJE NA STAVOVE STUDENATA
}

(Istorija novovekovne filozofije I i II i Filozofija vaspitanja i obrazovanja)

\begin{abstract}
Apstrakt: Ovaj rad deo je prve faze projekta departmana za filozofiju Uticaj kurseva filozofije na stavove studenata. Ciljevi ove faze projekta podrazumevali su 'osmišljavanje i formulisanje testova kojima će se proveravati vrednosni stavovi studenata', zatim 'sprovođenje testa', 'računanje rezultata' i na kraju 'analizu i interpretaciju rezultata'. Imajući u vidu naznačene ciljeve autori ovog rada pokušaće da obrazlože svoj dosadašnji angažman u navedenom projektu i da na osnovu analize i interpretacije dobijenih rezultata daju preporuke za pravac u kome bi dalje razvijali platformu za uspešan uticaj na sposobnost kritičkog mišljenja kod svojih studenata.
\end{abstract}

Ključne reči: kriterijumi formulacije, srednja vrednost, trend, plastičnost, verisimilitude.

Osmišljavanje i formulisanje testova

U svrhu dobijanja rezultata na osnovu kojih će se vršiti analiza i interpretacija vrednosnih stavova studenata, nastavnici i saradnici departmana za filozofiju sastavili su test od 66 konstatacija u pogledu kojih su studenti imali da izraze svoje slaganje ili neslaganje na skali koja se kretala od 1 do 5:

1. uopšte se ne slažem (srednja vrednost od 1 do 1,49$)^{1}$

2. većinom se ne slažem (srednja vrednost od 1,5 do 2,49 )

3. nisam siguran/-na (srednja vrednost od 2,5 do 3,49 )

4. većinom se slažem (srednja vrednost od 3,5 do 4,49 )

5. u potpunosti se slažem (srednja vrednost od 4,49 do 5)

Svakako, treba napomenuti da je domen konstatacija u pogledu kojih su studenti imali da izraze svoje stavove različit s obzirom na populaciju kojoj pripadaju. Tako su studenti prve dve godine imali da izraze svoje mišljenje s obzirom na 66 zadatih konstatacija, studenti treće u pogledu 37, a studenti četvrte godine s obzirom na 12 konstatacija. Ovo se može protumačiti preko zastupljenosti izvesnih tema koje se prorađuju na određenoj godini studija. Budući da su predmeti na prve dve godine studija opštijeg karaktrera i unutar svojih problemskih oblasti obrađuju teme koje će se kasnije iznova prorađivati iz drugih perspektiva, ovakva postavka pronalazi svoj

\footnotetext{
${ }^{1}$ Iznosimo raspon srednjih vrednosti jer će on biti baza na osnovu koje ćemo opisno vrednovati dobijene odgovore.
} 
smisao. Tako se, kroz predmete Uvod u filozofiju, Istoriju logike, Istoriju etike... obrađuju i neke teme koje se mogu smatrati vezanim za problematiku koju će studenti docnije iznova obrađivati kroz predmete Istorija novovekovne filozofije I i II i Filozofija vaspitanja i obrazovanja.

U osmišljavanju pomentutih konstatacija svaki od profesora i saradnika imao je zadatak da odredi koji stavovi iz njihove uže filozofske oblasti mogu na najbolji način poslužiti kao polazna osnova za opisivanje vrednosnih stavova studenata, te da na osnovu toga interpretacija i analiza dobiju najbolji mogući smer. Imajući ovo u vidu, autori ovog rada svoj su angažaman ispunili osmišljavajući i nudeći 11 konstatacija koje su procenili kao najbolju bazu za ispitivanje stavova studenata iz predmeta na kojima su angažovani. Sadržinski gledano naše konstatacije je trebalo da posluže kao baza za ispitivanje slaganja ili neslaganja njihovih intuicija sa onime što im je ponuđeno kroz tematiku obrađivanu iz predmeta Istorija novovekovne filozofije I i II i iz predmeta Filozofija vaspitanja i obrazovanja. Naravno, treba imati na umu i činjenicu da se teme iz navedenih predmeta, kako smo već napomenuli, prorađuju i kroz druge predmete, pre svega u prvoj i drugoj godini, ali iz drugih perspektiva. Otuda je populacija studenata koja je imala da izrazi svoje mišljenje u odnosu na predložene konstatacije podrazumevala prve tri godine osnovnih studija filozofije.

Iz perspektive tematike koja se prorađuje na predmetima Istorija novovekovne filozofije I i II ponuđene su sledeće konstatacije:

1. Da bi se saznao deo neke pojave neophodno je znati i celinu te pojave.

2. Najpreciznijim šestarom moguće je nacrtati savršen krug.

3. Brojevi su deo fizičke realnosti.

4. Svi zamislivi koncepti mogu se vizuelno predstaviti.

Iz perspektive predmeta Filozofija vaspitanja i obrazovanja postavljene su sledeće konstatacije:

5. Dobro vaspitanje posledica je dobrog obrazovanja.

6. Za oblikovanje karaktera najvažnije su nasledne osobine.

7. Cilj vaspitanja dece je poštovanje autoriteta.

8. Nije moguće vaspitanje odrasle osobe.

9. Vaspitanje i obrazovanje u jednoj zemlji su potpuno odvojeni od politike.

10. Za vaspitanje je centralno ono što se „nosi iz kuće”.

11. Pitanje dobrog vaspitanja određeno je društveno-političkim uređenjem jedne zemlje.

Prilikom formulisanja ovih konstatacija imali smo u vidu nekoliko kriterijuma. Ovi kriterijumi deo su uputstava koje preporučuju teoretičari argumentacije, a u svrhu što preciznijeg poklapanja stavova sa konceptima koji im stoje u osnovi. Prvi od njih ticao se zahteva da konstatacije koje smo formulisali predstavljaju jasnu tačku gledišta u pogledu problema na koji se odnose. Drugi kriterijum ticao se zahteva da u svakoj konstataciji postoje ključne reči ili kako to savremeni teoretičari kritičkog mišljenja nazivaju 'signalne reči' koje nekad implicitno, nekad eksplicitno predstav- 
ljaju jedan ili oba dela disocijativnog para unutar koncepta u kome se prorađuju. Treći kriterijum sastojao se u tome da svaka konstatacija podržava neki pozadinski koncept vezan za tematiku koja se prorađuje na našim predmetima. Prostim skeniranjem nekih od konstatacija moguće je obrazložiti ispunjenost ovih kriterijuma. Recimo da su u prvoj konstataciji ključne reči 'deo' i 'celina' kao disocijativni par, a da je pozadinski koncept u kome se one javljaju određen Hegelovim stavom iz $\mathrm{Fe}$ nomenologije duha: „Istinito jeste celina” (Hegel, 1979, p. 11). Naravno, Hegelova konstatacija ne bi bila dobra osnova za polazište ispitivanja, budući da više izražava konačan stav nego sugestiju o kojoj valja promisliti. Mi smo je zbog toga izrazili u nešto plastičnijoj ili da budemo precizniji prikrivenijoj formi. Ako za primer uzmemo četvrtu konstataciju, onda uviđamo da su ključne reči 'koncept' i 'vizuelno predstavljanje'. Pozadina ove konstatacije određena je Dekartovim stavom da: „Ako pak želim misliti o »tisućokutniku«, doduše dobro razumijem kako je to lik što se sastoji od tisuću stranica [...] ali tih tisuću stranica ne zamišljam na isti način, niti ih vidim kao da su nazočne" (Descartes, 1994, p. 142). U globalu sagledano i ostale konstatacije iz korpusa Istorije novovekovne filozofije II II imale su za cilj da ispitaju disocijaciju ${ }^{2}$ između razuma i empirije, te da isprovociraju intuicije naših studenata u pogledu razumevanja fundamenata našeg saznanja. Ukoliko iznova pokušamo da definišemo osnovu od koje smo pošli, onda se još jedared možemo osvrnuti na Dekartov stav po kome je: „... ono za što mišljah da vidim očima, shvaćam tek sposobnošću prosudbe koja je u mojem duhu" (Descartes, 1994, p. 62).

Isti manir osmišljavanja konstatacija prisutnih u testu vodio nas je i kada smo nastojali da istražimo njihove intuicije vezane za vaspitno-obrazovnu problematiku. Globalni pozadinski koncept od koga smo pošli, a što sugerišu i naše eksplicirane konstatacije tiče se dve disocijacije koju savremeni teoretičari prepoznaju, u prvom slučaju na relaciji vaspitanje-obrazovanje (upbringing and education), a u drugom na relaciji priroda-okolina (nature and nurture). Tako se pitanje 5 kreće u domenu prvog disocijativnog para koji se naslućuje kroz upotrebu signalnih reči u ovom slučaju 'vaspitanje' i 'obrazovanje', a pitanje 6 dovedeno u odnos sa pitanjima 9, 10 i 11 postavljeno je u kontekst drugog disocijativnog para. Otuda ključne reči 'karakter', 'politika', 'ono što se nosi iz kuće'... koje se javljaju u ovim konstatacijama ispituju njihove intuicije o ključnim faktorima koji mogu figurirati kao dominantni u njihovom viđenju vaspitanja i obrazovanja. Konstatacije 7 i 8 takođe mogu biti posmatrane kroz istu prizmu, ali ipak napominjemo da su disocijacije unutar njih nešto specifičnijeg karaktera.

\section{Sprovođenje testa i računanje rezultata}

Kao što smo već napomenuli populacija studenata koja je imala da izrazi svoje mišljenje, a vezano za konstatacije koje smo sastavili, podrazumevala je prve tri godine osnovnih studija filozofije. Precizan broj studenata čije stavove imamo da analiziramo iznosi 17 (I godina 6 studenata, II godina 8 studenata, III godina 3 stu-

\footnotetext{
${ }^{2}$ Treba napomenuti da se značenje termina 'disocijacija' u filozofskoj upotrebi umnogome razlikuje od njegovog značenja u drugim naučnim disciplinama, poput npr. psihologije.
} 
denta). Test je radi dobijanja što preciznijih rezultata sproveden u prvom i u drugom semestru na svakoj od godina koju smo testirali. S obzirom na ovakvu situaciju i s obzirom na konačan zahtev koji smo imali pred nama, definisan u konkursnoj dokumentaciji kao 'prikupljanje empirijskih podataka o promeni vrednosnih stavova studenata pre i nakon slušanja datih filozofskih kurseva', smatrali smo da je najbolje da izračunamo srednje vrednosti njihovih odgovora po godini studija. Naime, smatrali smo da se ovakvim računanjem obezbeđuje najbolja baza za uvid u promene vrednosnih stavova, te $\mathrm{u}$ trendove koje takve promene izražavaju. Tabela u kojoj su prikupljeni podaci izraženi kroz srednje vrednosti njihovih odgovora po godini studija je sledeća:

\begin{tabular}{|c|c|c|c|}
\hline \multirow{2}{*}{ Konstatacija } & \multicolumn{3}{|c|}{ Srednja vrednost brojčano } \\
\hline & I godina & II godina & $\begin{array}{c}\text { III } \\
\text { godina }\end{array}$ \\
\hline $\begin{array}{l}\text { 1. Da bi se saznao deo neke pojave neophodno je znati i } \\
\text { celinu te pojave }\end{array}$ & 3,41 & 4,06 & 4,16 \\
\hline 2. Najpreciznijim šestarom moguće je nacrtati savršen krug & 2,5 & 2,31 & 1,5 \\
\hline 3. Brojevi su deo fizičke realnosti & 2,5 & 2 & 1,83 \\
\hline 4. Svi zamislivi koncepti se mogu vizuelno predstaviti & 2,16 & 2,18 & 1,66 \\
\hline 5. Dobro vaspitanje posledica je dobrog obrazovanja & 2,16 & 2,31 & 2,00 \\
\hline 6. Za oblikovanje karaktera najvažnije su nasledne osobine & 2,25 & 2,12 & \\
\hline 7. Cilj vaspitanja dece je poštovanje autoriteta & 2,25 & 1,43 & 1,5 \\
\hline 8. Nije moguće vaspitanje odrasle osobe & 3,08 & 3,06 & 3,33 \\
\hline $\begin{array}{l}\text { 9. Vaspitanje i obrazovanje u jednoj zemlji su potpuno } \\
\text { odvojeni od politike }\end{array}$ & 2,5 & 2,12 & 2,5 \\
\hline 10. Za vaspitanje je centralno ono što se „nosi iz kuće” & 3,75 & 2,56 & 3,83 \\
\hline $\begin{array}{l}\text { 11. Pitanje dobrog vaspitanja određeno je društveno- } \\
\text { političkim uređenjem jedne zemlje }\end{array}$ & 3,16 & 2,5 & 3,16 \\
\hline
\end{tabular}

Imajući u vidu rezultate iznesene u gornjoj tabeli, moguće je primetiti nekoliko manira u kojima se kreću stavovi ispitivanih studenata. Recimo da se stavovi vezani za prve tri konstatacije kreću u pravcu od stava 'nisam siguran/-na' na prvoj godini studija ka preciznijim određenjima na ostalim ispitivanim godinama. Iz te perspektive prvo pitanje pokazuje trend ka pozitivnom odgovoru 'većinom se slažem', a drugo i treće trend ka negativnom odgovoru 'većinom se ne slažem'. Kroz odgovore na ostale konstatacije nije moguće uvideti jednosmeran trend kao u slučaju prve tri predstavljene konstatacije. Ostale konstatacije izuzev konstatacija 9 i 10, u kojima imamo prvo varijaciju 'nisam siguran/-na' - 'većinom se ne slažem' - 'nisam siguran/-na', a zatim i varijaciju većinom se slažem - nisam siguran/-na - većinom se slažem, pokazuju stabilne vrednosti u pogledu ponuđenih konstatacija. Tako srednje vrednosti za konstatacije 4, 5, 6 i 7 izražavaju vrednosni stav 'većinom se ne slažem', a srednje vrednosti konstatacija 8 i 11 izražavaju neutralan vrednosni stav 
tj. 'nisam siguran/-na'. Nakon, merenja i opisnog predstavljanja rezultata prelazimo na njihovu analizu i interpretacijiju.

\section{Analiza i interpretacija rezultata}

S početka, pre nego što krenemo u analizu i interpretaciju predstavljenih podataka, pokušali bismo da damo okvire iz kojih će se one kretati. Ti okviri u velikoj meri su rezultat našeg viđenja samog procesa kritičkog mišljenja i postavki na kojima je ono bazirano. Naime, mi ćemo na samom početku pokušati da analiziramo dobijene rezultate sa pozicije modela 'voštane ploče', te nastojati da uvidimo koliko su naši studenti 'postali svesni problema' koje su im sugerisale postavljene konstatacije i naravno njihovu mogućnost da izvesne intuicije promene. Na ovaj način, pokušaćemo da kod njih analiziramo 'plastičnost' preko koje su jedino u mogućnosti da prime i razviju forme neophodne za dalje napredovanje u kritičkom mišljenju o konceptima koje smo nastojali da izrazimo kroz navedene konstatacije. Tačnije, u prvu ruku, nastojaćemo da vidimo u kojoj meri smo uspeli da kod njih probudimo upitnost nad njihovim intuicijama i da sa te platforme damo dalje predloge za razvoj našeg projekta. No pre toga, probajmo da ukratko objasnimo koncept plastičnosti i njegovu vezu sa našom problematikom.

U knjizi Džona Djuia Pedagogika i demokratija nailazimo na jedno jako interesantno poglavlje u kome se afirmativno i pozitivno govori o nezrelosti. Iz te perspektive nezrelost je viđena kao ključni uslov razvoja u obrazovanju. Postavka se ukratko svodi na sledeće. Ukoliko smatramo da smo zreli u nekom domenu, utoliko ne uviđamo potrebu za daljim obrazovanjem i napredovanjem $\mathrm{u}$ istom. $\mathrm{U}$ tom smislu, naša namera vezana za postavljene konstatacije, pored ispunjenja formalnih kriterijuma u osmišljavanju, bila je i da pomoću njih probudimo, ma koliko paradoksalno zvučalo nezrelost. Idući dalje Djuievim tragom mi smo na taj način pokušali da proizvedemo plastičnost kao: „moć da se zadrži nešto od iskustva što bi bilo od koristi za savlađivanje budućih teškoća“ (Djui, 1934, p. 74). I premda Djui o ovoj plastičnosti govori kao o nečemu različitom od: „plastičnosti voska ili gline” (Djui, 1934, p. 74), te se u izvesnom smislu odvaja od tumačenja ovog koncepta kakvim ćemo ga mi predstaviti, ipak smatramo da ovakvo viđenje može biti od pomoći u razjašnjenju naše analize i interpretacije. Stoga pođimo od istorijskih korena ovakve postavke i probajmo da objasnimo kako se ona uzima u savremenom kontekstu.

Naime, Platon, u svom dobro poznatom dijalogu Teetet, iznosi jednu jako inspirativnu metaforu za naš sadašnji problem [Theaet. 191c]:

„Uzmi dakle zbog našeg sadašnjeg ispitivanja da u našim dušama postoji voštana ploča, kod jednog veća, kod drugoga manja. Kod jednog je od čišćeg voska, kod drugoga od prljvavijeg i tvrđeg, a kod nekih od mekšeg, dok kod nekih ima u pravoj mjeri” (Platon, 1979, p. 69).

Imajući u vidu ovo mesto Birneja iznosi svoje viđenje tzv. 'modela voštane ploče'. On će reći da se iz ove metafore može zaključiti: „,.. kako kapacitet za učenje 
i pamćenje varira od jedne osobe do druge u skladu sa kvalitetom njihovog voska" (Burnyeat 1990, 92). Mi naravno nećemo pratiti ove varijacije 'od jedne osobe do druge' već ćemo imati u vidu varijacije od jedne populacije studenata do druge. Osvrćući se, sa ove pozicije, na Djuievu prethodno interpretiranu koncepciju o nezrelosti i plastičnosti, možemo reći da se tek na platformi postojanja plastičnosti može razviti izvestan kvalitet za saznanje. Dalje, Birneja, idući ka preciznijem objašnjenju tvrdi: „... model voštane ploče je veoma efikasno sredstvo koje nas čini sposobnim da se u novoj percepciji odvojimo, kroz imaginaciju, od 'potpisa' koji joj je bio namenjen" (Burnyeat 1990, 92). Ako ovu osobinu sagledamo imajući u vidu vrednosti za sve dobijene odgovore, onda su rezultati dobri, budući da niti jedna vrednost u tabeli ne uzima radikalnu oznaku 'u potpunosti se slažem' ili 'u potpunosti se ne slažem'. Dakle, ovime je ispunjen zahtev za plastičnošću iz Djuieve perspektive 'da se zadrži nešto od iskustva što bi bilo od koristi za savlađivanje budućih teškoća', a to je u našoj interpretaciji viđeno, premda utvrđeno na osnovu nedostatka radikalnog stava, ipak afirmativno. Da izrazimo to preciznije, svaki od vrednosnih stavova u svom krajnjem izrazu ostavlja makar i u malom domenu prostora za sumnju i stoga za napredovanje.

Sve o čemu smo gore ukratko informisali navodi nas na pretpostavku po kojoj je plastičnost u svom krajnjem domenu zapravo sposobnost da se posumnja u svoje uvrežene intuicije i da se na bazi te sumnje intuicije promene. Ovako dvostruko postavljen koncept plastičnosti sagledaćemo sada iz prve perspektive, dakle iz pozicije postojanja sumnje $u$ vezi sa analiziranom konstatacijom. Na osnovu ove perspektive uviđamo da smo plastičnost kao sumnju uspeli da izazovemo imajući u vidu sve tri populacije ispitivanih studenata, kroz konstatacije koje su dovele do pozicije nisam siguran/-na. Takvu situaciju imamo u pitanjima 8 i 11. No, ovakav stav naših studenata dobar je samo u jednom domenu, tj. samo u domenu po kome je ostvareno polje za dalji razvoj. Dakle, odgovori na ove konstatacije sugerišu samo to da za nas postoji dobra osnova za dalju proradu teme, ali i nedostatak mogućnosti uvida u njihov vrednosni stav što je zapravo bio zahtev čitavog sprovedenog testiranja. No, u ostalim odgovorima na konstatacije koje smo postavili primetićemo i pojavu stavova koji na neki način pokazuju vrednosti slaganja ili neslaganja.

Ovo slaganje ili neslaganje analiziraćemo i interpretirati preko Poperovog pojma 'verisimilitude', kojim se zapravo određuje nečije saznanje kao: ,... bliže sličnosti sa istinom ili bolje korespondira sa činjenicama" (Popper 1995, 233). Mi ćemo se naravno odmah ograditi od analize toga da li stavovi naših studenata korespondiraju sa činjenicama. Zbog čega to činimo izvestićemo u zaključku našeg rada. Za sada samo možemo uvideti da neki od vrednostnih stavova naših studenata mogu biti razmatrani kao manje ili više korespondirajući sa datom konstatacijom. Tako odgovori na konstatacije 4, 5, 6 i 7 naginju ka tome da ne korespondiraju sa njihovim primarnim intuicijama. Iz perspektive predmeta koje sa njima prorađujemo ovi odgovori su zapravo zahtevani, ali ipak ne uviđamo ma kakav trend u razvoju ovih intuicija. One su iste podjednako na I, II i III godini. I premda po svom usmerenju pogađaju ono što se uči na našim predmetima, mi zapravo ne uviđamo razvoj tog učenja, tačnije ne možemo sa punom sigurnošću reći da su ovi vrednosni stavovi fundirani isključivo na saznanjima koja su stekli tokom svog školovanja, mada je to moguće. 
Ako tako postavimo stvari, onda poslednja grupa pitanja koju analiziramo i interpretiramo najbolje indikuje platformu da je poučavanje u izvesnim oblastima ispunilo svoj cilj, te na neki način zaista pokazuje promene u vrednosnim stavovima naših studenata. Recimo, na ovom mestu da je cilj poučavanja u kritičkom mišljenju kao globalni cilj celokupnog obrazovanja u filozofiji definisan kroz projektnu dokumentaciju, doduše iz perspektive etike, na način da 'student koji je pre nastave iz etičkih kurseva bio (po svojim intuicijama) konsekvencijalista, može nakon te nastave zauzeti više deontološku poziciju ili obratno'. Nešto šire sagledano i vezano za konstatacije koje se tiču naše problematike ovakav trend uviđamo, kao što smo već istakli kod pitanja 1, 2, 3, 9 i 10. Jedino kod ovih pitanja vidimo plastičnost $u$ onom širem smislu po kome se sluti promena u našoj analizi od pozicije nesigurnosti ka većem ili manjem slaganju ili od pozicije slaganja ili neslaganja ka poziciji nesigurnosti. Kako mi to interpretiramo ove konstatacije u dovoljnoj meri se uklapaju u oba gore navedena konteksta o kojima smo ukratko izvestili i jedino na osnovu njih je moguće dati informacije o promeni vrednosnih stavova.

Tako, na kraju, možemo potvrditi, sa izvesnom rezervom, da je naš cilj u razvoju kritičkog mišljenja postignut imajući u vidu obradu tema koje se tiču uglavnom Istorije novovekovne filozofije I i II (pitanja 1, 2, 3). Jedino kroz odgovor na ove konstatacije uviđamo zahtevani trend $i$ ispunjenost dva prethodno postavljena kriterijuma izazivanje plastičnosti i dolaženje do 'verisimilitude'. U pogledu odgovora na konstatacije 9 i 10 koje proizilaze iz domena Filozofije vaspitanja i obrazovanja, uviđamo doduše spoj plastičnosti kao sumnje i izvesnih naznaka kretanja ka 'verisimilitude', ali ne kao trend već kao varijaciju koja ne daje dobru osnovu za uviđanje stabilnog trenda, već pre ukazuje na slučajnu promenu u njihovim stavovima.

\section{Zaključak}

Analiza i interpretacija prethodnih rezultata kao prvi deo projekta departmana za filozofiju navodi nas na to da damo dalje preporuke za moguće unapređenje uvida u promene vrednosnih stavova studenata. Pre svega jasno je da statistička obrada podataka u našem slučaju pokazuje izvesne manjkavosti s obzirom na postavljeni cilj. Ta manjkavost posledica je kako malog i različitog broja studenata u populacijama koje smo ispitivali, tako i generalnih nedostataka modela testiranja kao dovoljnog da pokrije sve kriterijume koji najpreciznije označavaju ove promene. Ipak, ukoliko se ovi podaci uzmu samo kao polazna osnova za dalje sprovođenje projekta, možemo se nadati boljim dometima u konačnom zahtevu koji je postavljen u konkursnoj dokumentaciji.

$\mathrm{S}$ jedne strane, sprovedeni test premda pruža uvid u manji ili veći razvoj plastičnosti i 'verisimilitude' ipak ne može da pokrije čitavo polje evidencione baze koja nam je potrebna za precizan uvid u promenu vrednosnih stavova. Ovi koncepti zahtevaju zapravo jednu širu evidencionu bazu koja će dati precizniji uvid u prave promene njihovih stavova, a koje samim načinom ovako postavljenog testiranja ne možemo da izborimo. Recimo da njihovi izrazi nesigurnosti u pogledu slaganja ili 
neslaganja sa datom konstatacijom možda ne sugerišu da oni zapravo nemaju nikakav stav u pogledu ispitivanog pitanja. Možda je neophodno preciziranje navedenih konstatacija koje su ovde fiksirane i ne mogu se dalje precizirati. Često se i kroz našu nastavnu praksu javljaju koncepti koji su manje-više kontrarni i nije moguće izneti precizniji stav 'na prvu loptu'. Takođe, i u pogledu odgovora koji izražavaju njihov stav slaganja ili neslaganja, sama sigurnost u taj postavljeni stav kao i pravi razlozi njihovih promena kroz godine studija ne mogu biti obrazloženi na osnovu ovako sprovedenog testa. Prema svemu ovome jasno je da posle prvog ispitivanja stavova studenata ostaje mnogo otvorenih pitanja. Pomenute teškoće određuju smer u kome nadalje treba fokusirati buduća istraživanja.

Dakle, preciznost sa kojom se može bolje razmatrati promena vrednosnih stavova naših studenata može biti poboljšana preko izvesnih kriterijuma koji se nalaze u drugim oblicima ispitivanja. Kroz test mi ne vidimo argumentativne tehnike koje oni imaju u vidu kada dolaze do svojih odgovora. Ne vidimo strukturu njihovih misli niti to da li su možda doneseni na bazi nekih emotivnih ili drugih razloga. Iz te perspektive njihovi odgovori na ovom nivou mogu se uzeti samo kao lake generalizacije (soft generalizations), ali ne i kao stav koji u pozadini ima dobru evidencionu bazu i njeno koherentno razumevanje. Otuda predlažemo da se druga faza razvoja projekta kreće kroz analizu i interpretaciju njihovih vrednosnih stavova kroz diskusije i debate na zadate teme. Precizniji uvid u njihove vrednosne stavove, izražene kroz pomenutu razmenu misli, svakako bi bio korak dalje u razvoju ovog istraživanja. Sama živost ovih metoda može dodatno doprineti razumevanju pozitivnih i negativnih strana u njihovom mišljenju.

Ne treba zaboraviti da konačni cilj ovog projekta treba da dokaže da student 'može uticati i menjati stavove građana o bitnim temama od javnog značaja, kakvi su nauka, religija, vaspitanje, moral, umetnost itd'. Iz te perspektive nije dovoljno posedovati samo izvestan korpus informacija čiji uvid nam je omogućio sprovedeni test. Iz šire perspektive kao kritički mislilac on treba da na neki način manipuliše tim informacijama u pravom smeru i na pravi način što je opet tehnika koja se može steći jedino implementiranjem diskusija i debata unutar saznajnog procesa. Ovde se još jedanput jasno pokazuje u kom pravcu treba dalje razvijati ovaj projekat. Naravno i to je moguće samo u ograničenom domenu, ali, ograničavajući se na kraju samo na polje našeg sprovedenog istraživanja, ove tehnike se nameću kao validna osnova za precizniji uvid $u$ ispravnost njihovog mišljenja o navedenim konstatacijama s jedne strane, a sa druge i kao moćno sredstvo kojim će u budućnosti imati da menjaju i utvrđuju teme od javnog značaja.

\section{Literatura}

Burnyeat, M. (1990). The Theaetetus of Plato. Indianapolis/Cambridge: Hackett Publishing Company.

Descartes, R. (1994). Metafizičke meditacije. Zagreb: Demetra. 
Djui, D. (1934). Pedagogika i demokratija. Beograd: Geca Kon.

Hegel, G. V. (1979). Fenomenologija duha. Beograd: BIGZ.

Platon. (1979). Fileb, Teetet. Zagreb: Naprijed.

Popper, K. (1995). Conjectures and Refutations. London: Routledge.

\title{
THE INFLUENCE OF PHILOSOPHY COURSES ON STUDENTS`ATTITUDES
}

\begin{abstract}
This paper is part of the first phase of the Department of Philosophy project "The Influence of Philosophy Courses on Students' Attitudes". The goals of this phase of the project included designing and formulating tests that will check students values, then conducting a test, calculating results and finally analyzing and interpreting results. Having in mind the stated goals, the authors of this paper will try to explain their previous engagement in the mentioned project and, based on the analysis and interpretation of the obtained results, give recommendations for the direction in which they would further develop a platform for successful influence on critical thinking.
\end{abstract}

Keywords: formulation criteria, middle value, trend, plasticity, verisimilitude. 